\section{Effect of Dental Pigmentation Intensity on the Transenamel and Transdentinal Penetration of Hydrogen Peroxide}

Janaina Cardoso Moreira ${ }^{1}$, Marjorie de Oliveira Gallinari ${ }^{1}$, Vanessa Rahal${ }^{1}$, Ticiane Cestari Fagundes', Paulo Henrique dos Santos², Marcia Regina de Moura $^{3}$, André Luiz Fraga Briso ${ }^{1}$

\author{
'Department of Restorative \\ Dentistry, Araçatuba Dental \\ School, UNESP - Univ Estadual \\ Paulista, Araçatuba, SP, Brazil \\ ${ }^{2}$ Department of Dental Materials and \\ Prosthodontics, Araçatuba Dental \\ School, UNESP - Univ Estadual \\ Paulista, Araçatuba, SSP, Brazil \\ ${ }^{3}$ Department of Physics and Chemistry, \\ FEIS, UNESP - Univ Estadual \\ Paulista, 1ha Solteira, SP, Brazil \\ Correspondence: Prof. Adj. André \\ Luiz Fraga Briso, Rua José Bonifácio, \\ 1193, 16015-050 Araçatuba, São \\ Paulo, Brasil. Tel: +55-18-3636- \\ 3200. e-mail: alfbriso@foa.unesp.br
}

Key Words: pigmentation, dental bleaching, hydrogen peroxide.

\section{Introduction}

Body and facial aesthetics are becominDWncreasingly important for social acceptance and personal and professional success in modern society. Therefore, there is a strong demand for products and procedures that can improve personal appearance (1). Oral aesthetic standards are well defined and, for most people, an appealing smile is related to the presence of aligned, well-shaped and lighter teeth. For this reason, one of the most common complaints in dental offices are related to the color of the teeth, which may be naturally dark and can undergo changes in color over time (2-4).

These color alterations may be classified as extrinsic, intrinsic or internalized discoloration. The latter can occur when pigments from food dyes or beverages such as black tea permeate the tooth through structural defects in the enamel and cause intrinsic discoloration $(5,6)$.

Among the various aesthetic treatments available for correction of chromatic alterations, dental bleaching has proven to be a popular option and considered as technically easier, less invasive and relatively inexpensive compared to other options, and it provides excellent results (7-9). The change in color that occurs during bleaching treatment is predominantly due to the increased brightness of the teeth and this factor has been widely studied to analyze the effectiveness of various bleaching techniques $(5,10)$.

The most accepted theory regarding the mechanism of action of dental whiteninDWs based on the formation and penetration of extremely reactive oxygen free radicals that break down the pigment molecules present within the tooth structure, resultinDWn lighter teeth $(11,12)$. Dental tissues that have different levels of pigment saturation are expected to absorb different amounts of peroxide from bleaching products. The confirmation of this supposition would result in great improvements in the development of individualized and safe therapies, avoiding the unwanted penetration of reactive oxygen species into the pulp tissue (13-17), which has been related to cell damage $(11,12)$ and clinical symptoms $(2,18)$.

In such context, the purpose of this study was to evaluate the effect of different levels of dental pigmentation on the transenamel and transdentinal penetration of hydrogen peroxide $\left(\mathrm{H}_{2} \mathrm{O}_{2}\right)$ during bleaching treatment. Therefore, the null hypothesis is that pigmentation intensity does not influence the transenamel and transdentinal penetration of hydrogen peroxide during the bleaching treatment.

\section{Material and Methods Experimental Design}

This investigation included the following study factors: 
1. Pigmentation intensity at 3 levels (no pigmentation, moderate pigmentation and severe pigmentation); 2. Evaluation times at 3 levels (after the first, second and third bleaching sessions).

The response variables were the transenamel and transdentinal penetration of hydrogen peroxide as well as the $L^{*}$ values.

\section{Collection and Preparation of Specimens}

One hundred healthy incisors from young cattle were obtained from a local abattoir. The teeth were cleaned and stored in $0.1 \%$ thymol solution. Later, $5.7 \mathrm{~mm}$-diameter experimental units (enamel/dentin discs) were obtained from the middle third of the buccal surface of these teeth.

The dentin surface of each disc was manually tapered using sandpaper (\#400 and \#600) (T469-SF-Norton, SaintGobain Abrasivos Ltda, Jundiai, SP, Brazil) until the final thickness reached $3.5 \mathrm{~mm}$, or approximately $1.3 \mathrm{~mm}$ and $2.2 \mathrm{~mm}$ for the enamel and dentin, respectively.

\section{Sample Selection}

One hundred dental discs were obtained and subjected to an initial reading of $L^{*}$ using an ultraviolet/visible r reflection spectrophotometer (UV-2450, Shimadzu, Kyoto, Japan) at a wavelength of $596 \mathrm{~nm}$. After obtaining the $L^{*}$ (between 93.39 and 57.30), the median of the whole sample was calculated. Then, 60 dental specimens presenting $L^{*}$ values closer to the median with a tolerance level of $5 \%$ were selected.

\section{Pigmentation of Samples and Study Groups}

The specimens were randomly divided into three experimental groups depending on the used pigmentation protocol: DW - The specimens remained immersed in distilled water at $37^{\circ} \mathrm{C}$ throughout the experiment. BT100 - The specimens were immersed for 6 days in a black

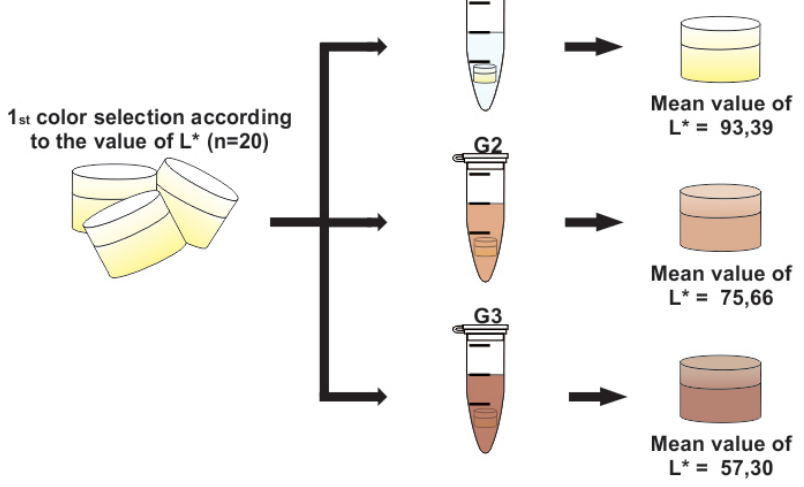

Figure 1. Experimental flowchart showing the sample selection and pigmentation process. tea infusion (Matte Leão, Curitiba, PR, Brazil) at $37{ }^{\circ} \mathrm{C}$, prepared with $100 \mathrm{~mL}$ of distilled water per $1.6 \mathrm{~g}$ of tea. BT10 - The specimens were immersed for 6 days in a black tea infusion (Matte Leão) at $37{ }^{\circ} \mathrm{C}$, prepared with $10 \mathrm{~mL}$ of distilled water per $1.6 \mathrm{~g}$ of tea. In order to remove the extrinsic pigmentation after the treatments, the enamel surface was carefully treated with pumice and water using a Robinson brush (KG Sorensen Ind e Com. Ltda, Barueri, SP, Brazil) at low speed. Next, the specimens were thoroughly washed under running water for $3 \mathrm{~min}$. After completing the pigmentation process, a second sample selection was performed according to the method described above. Specimens that showed no chromatic stratification were excluded, and 15 dental specimens remained in each study group $(n=15)$ Thus, the $L^{*}$ values for the three groups were distributed as follows: DW > BT100 > BT10 (Fig. 1)

\section{Preparation of the Artificial Pulp Chamber (APC)}

The dentin surface of all blocks was treated with ethylene diamine tetra acetic acid solution for $1 \mathrm{~min}$ to remove the smear layer and next the discs were washed with deionized water for $20 \mathrm{~s}$.

Next, the blocks were placed into artificial pulp chambers $(19,20)$ (APCs), which were composed of two compartments. The upper compartment had an 8-mm aperture diameter at the bottom and another portion with a 6-mm aperture, allowing adaptation to the specimen. The lower compartment had lateral perforations that allowed circulation of the solution used to quantify the $\mathrm{H}_{2} \mathrm{O}_{2}$ that penetrated the specimen. To assist in the setting of the dental blocks, were used two silicone rings with a $4.47 \mathrm{~mm}$ internal diameter and $1.78 \mathrm{~mm}$ thick (OR 008; Rolemag - Rolamentos e Peças Ltda, Araçatuba, SP, Brazil) and pink molten wax.

\section{Transenamel and Transdentinal $\mathrm{H}_{2} \mathrm{O}_{2}$ Penetration}

The properly constructed APCs were placed in cell

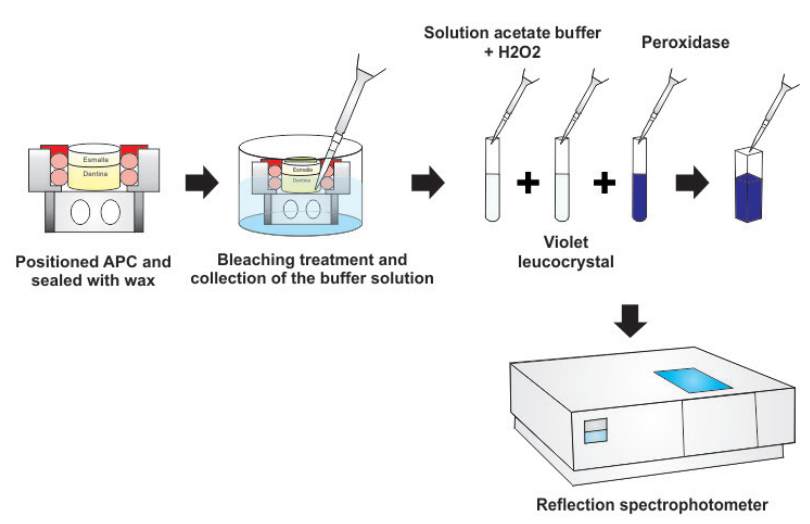

Figure 2. Experimental flowchart showing the transenamel and transdentinal penetration of $\mathrm{H}_{2} \mathrm{O}_{2}$. 
culture plates (CorninDWncorporated, Corning, NY, USA) containing $1 \mathrm{~mL}$ of an acetate solution that permeated and stabilized the $\mathrm{H}_{2} \mathrm{O}_{2}$ during the bleaching procedure. For the bleaching procedure, the dentin surface of each specimen remained in contact with this solution. $\mathrm{H}_{2} \mathrm{O}_{2}$ diffused through the tooth structure and incorporated into it. A violet dye solution $(0.5 \mathrm{mg} / \mathrm{mL}$; Sigma Chemical Co, St Louis, MO, USA) was added together with a solution of Leuco Crystal peroxidase enzyme, ( $1 \mathrm{mg} / \mathrm{mL}$; Sigma) and the resulting solution changed the color according to the amount of $\mathrm{H}_{2} \mathrm{O}_{2}$ in the sample (32-34). Measurements were performed after each bleaching session using an ultraviolet/visible reflection spectrophotometer (Ultraviolet Visible Model UV-2450; Shimadzu) and a graph plotting absorbance against concentration was prepared (Fig. 2).

\section{Analysis of the $L^{*}$ Values}

Immediately before the bleaching procedure and $24 \mathrm{~h}$ after each session, the specimens were cleaned, dried and placed in an ultraviolet/visible light reflection spectrophotometer (Ultraviolet Visible Model UV-2450; Shimadzu). Three readings were performed on the labial surface of each specimen and the median $L^{*}$ value was recorded at each evaluation time. The axial $L^{*}$ represents the luminosity and extends from 0 (black) to 100 (perfect white).

\section{Bleaching Procedure}

The bleaching treatment was performed using a 38\% hydrogen peroxide product (Opalescence Xtra Boost, Ultradent Products Inc., South Jordan, UT, USA) according

Table 1. Mean $\mathrm{H}_{2} \mathrm{O}_{2}$ concentration $(\mu \mathrm{g} / \mathrm{mL})$ that permeated through the dental tissues during the bleaching treatment according to the different evaluation times and pigmentation levels of the teeth

\begin{tabular}{lccc}
\hline Group & T1 & T2 & T3 \\
\hline Control (GI) & $6.25(0.4) \mathrm{Aa}$ & $6.02(0.5) \mathrm{Aa}$ & $6.47(0.5) \mathrm{Aa}$ \\
Moderate (GII) & $5.26(0.5) \mathrm{Bb}$ & $5.69(0.8) \mathrm{Aa}$ & $6.58(0.6) \mathrm{Aa}$ \\
Severe (GIII) & $5.20(0.4) \mathrm{Bb}$ & $5.95(0.4) \mathrm{Aab}$ & $6.15(0.3) \mathrm{Aa}$ \\
\hline
\end{tabular}

Different letters (uppercase in columns and lowercase in rows) indicate statistically significant differences $(\mathrm{p}<0.05)$.

Table 2. Mean values of $\mathrm{L}^{*}$ in bleached teeth presenting different levels of pigmentation

\begin{tabular}{|c|c|c|c|c|}
\hline Group & Baseline & $\mathrm{T} 1$ & $\mathrm{~T} 2$ & T3 \\
\hline Control (GI) & $93.39(0.8) \mathrm{A} \mathrm{c}$ & $93.88(0.7) \mathrm{A}$ bc & $94.63(1.0) \mathrm{A} a b$ & $95.41(1.2) \mathrm{A} \mathrm{a}$ \\
\hline Moderate (GII) & 75.66 (6.3) B c & 84.63 (3.7) B bc & $88.51(3.1) \mathrm{B} \mathrm{ab}$ & 95.06 (2.9) A \\
\hline Severe (GIII) & 57.30 (5.3) C c & 78.16 (5.2) C bc & $85.03(4.0) \mathrm{B} a b$ & $87.10(3.9) \mathrm{B} \mathrm{a}$ \\
\hline
\end{tabular}

Different letters (uppercase in columns and lowercase in rows) indicate statistically significant differences $(\mathrm{p}<0.05)$. to the manufacturer's instructions. Afterwards, the product was inserted into a disposable graduated syringe and 0.04 $\mathrm{mL}$ of the gel was applied to each specimen. Three 15-min applications were conducted for each sample and the tooth surface was cleaned with cotton and absorbent paper before each application. The procedure was performed in three different sessions, once weekly.

\section{Statistical Analysis}

The $\mathrm{L}^{*}$ values and transenamel and transdentinal penetration of $\mathrm{H}_{2} \mathrm{O}_{2}$ were tabulated and submitted to a normality test. Then, the data were submitted to the Friedman and the Kruskal Wallis tests at a 5\% significance level.

\section{Results}

Transenamel and Transdentinal Penetration of $\mathrm{H}_{2} \mathrm{O}_{2}$

Table 1 shows that in the first bleaching session, the control group showed greater transenamel and transdentinal penetration of $\mathrm{H}_{2} \mathrm{O}_{2}$ than the pigmented groups (BT100 and BT10), which were similar to each other. However, in the second and third bleaching sessions, all groups showed similar results.

Analyzing the behavior of each group separately, DW maintained the same level of penetration in all three bleaching sessions. Conversely, the penetration of $\mathrm{H}_{2} \mathrm{O}_{2}$ tended to increase in the pigmented groups during the bleaching treatment.

\section{$L^{*}$ Values}

Table 2 shows that the chromatic stratification resulted in decreasing values of $L^{*}$ before the bleaching treatment (baseline) and the stratification remained the same even after the first bleaching session ( $\mathrm{T} 1$ ). The pigmented groups (BT100 and BT10) presented similar $\mathrm{L}^{*}$ values at T2 and T3 and the values remained lower than those of the control group did. At T3, the control group and the moderate pigmentation groups (DW and BT100) showed similar L* values, statistically different from the severe pigmentation group (BT10) (Fig. 3).

All groups presented an increase in the $L^{*}$ values after bleaching.

\section{Discussion}

The low molecular weight of $\mathrm{H}_{2} \mathrm{O}_{2}$ allows it to spread rapidly through the tooth structure and reach the dentin tissue shortly after the application of a bleaching agent to the enamel $(14,17)$. It is assumed that $\mathrm{H}_{2} \mathrm{O}_{2}$ and products derived from its decomposition 
react with chromophores, breaking them down into smaller compounds and resultinDWn lighter teeth (21).

Unfortunately, this oxidation reaction is not limited to chromophores and may cause a number of undesirable side effects $(13,14)$. For this reason, studies evaluating the penetration of $\mathrm{H}_{2} \mathrm{O}_{2}$ into the pulp chamber are required to establish a safe and effective bleaching therapy.

In the present investigation, bovine teeth were used due to their uniform composition and similarity to human teeth as to morphology and histology, beyond the facility to obtain them and standardize the samples, and have few variations of experimental responses in laboratory research (22).

The methodology used for quantifying the transenamel and transdentinal penetration of $\mathrm{H}_{2} \mathrm{O}_{2}$ in this study was based on the method previously reported by Mottola et al. (1970) (23), which is extremely sensitive for detecting small amounts of $\mathrm{H}_{2} \mathrm{O}_{2}$. In this study, the contact between the dentin surface and the buffer solution allowed for stabilization in the APC and posterior quantification of the $\mathrm{H}_{2} \mathrm{O}_{2}$ from the bleaching product and diffused through the dental tissues by spectrophotometry.

Color alterations before and during the bleaching therapy were evaluated based on the luminosity due to its high correlation with the effectiveness of bleaching treatment (10).

Exposure of the dental fragments to the different infusions of black tea allowed the diffusion of the chromophores through the system of dentinal tubules and through the inter-tubular dentine, producing effectively different levels of pigmentation (6).

The analysis performed after the first bleaching session showed that initially the pigmentation influenced negatively the permeation of $\mathrm{H}_{2} \mathrm{O}_{2}$ through tooth structure, therefore the null hypothesis of this study was rejected. One possibility is that catechin, a phenolic ultra-antioxidant

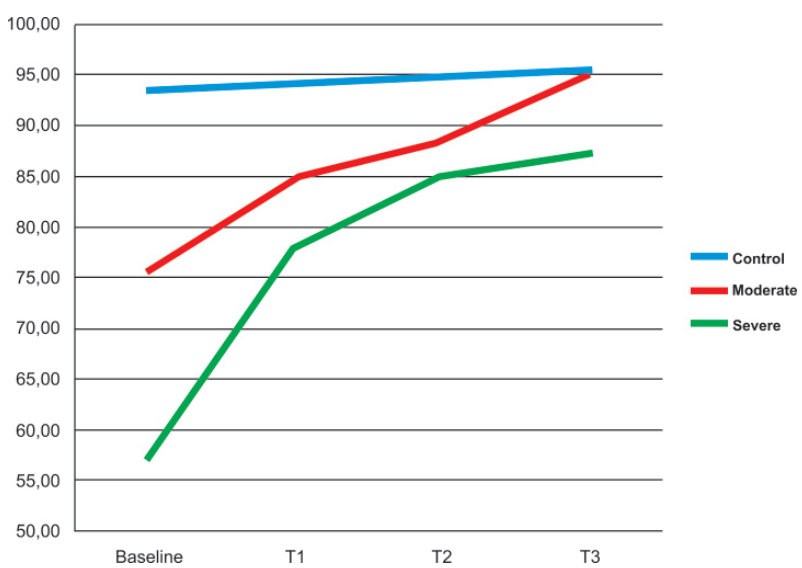

Figure 3. Mean $\mathrm{L}^{*}$ values according to the different study groups. found in large amount in black tea, consumed the $\mathrm{H}_{2} \mathrm{O}_{2}$ released by the bleaching product, reducing the amount available to react with the buffer solution. This would explain the different penetration levels between the study groups (24).

After the bleaching sessions, although the $L^{*}$ values were considerably closer, the more pigmented teeth did not reach the values of the control group and this observation was visually confirmed. On the other hand, the penetration of $\mathrm{H}_{2} \mathrm{O}_{2}$ was similar in all study groups after the second session.

A plausible explanation for this finding may be the possible association between the catechin hydroxyl radical and the calcium in the tooth structure. This may result in formation of more complex chains and links that are less able to propagate oxidative reactions, impairing the ability of $\mathrm{H}_{2} \mathrm{O}_{2}$ to transform high-molecular-weight compounds into low molecular weight compounds.

Besides, the catechin molecule contains many alcohol (24) groups and may react with oxygen from the bleaching agent. This would result in a compound that is rich in acetone, which may inhibit the oxidative effects of $\mathrm{H}_{2} \mathrm{O}_{2}$, without interfering with its penetration in the tooth structure (24).

Even considering the reduced penetration of $\mathrm{H}_{2} \mathrm{O}_{2}$ at the beginning of the bleaching therapy in the most pigmented teeth, this reduction was generally not significant enough to indicate a need for more intensive therapies in teeth with more severe color alterations. It has been reported that aggressive $\mathrm{H}_{2} \mathrm{O}_{2}$ exposure can be damaging to the pulp cells, even when the amount of $\mathrm{H}_{2} \mathrm{O}_{2}$ that reaches the pulp tissue is considerably lower than the one found in the present study (25).

This study presents some limitation since only one kind of extrinsic pigmentation was evaluated. Further studies should be conducted with other kinds of extrinsic and intrinsic pigmentations. Other analyses should also be evaluated, like the formation of molecular compounds, to elucidate the mechanisms of bleaching treatment involving substrates with varying degrees of darkened teeth. Based on the results obtained in this study, it may be concluded that pigmentation may reduce the transenamel and transdentinal penetration of $\mathrm{H}_{2} \mathrm{O}_{2}$ at the beginning of bleaching treatment.

\section{Resumo}

Este estudo teve como objetivo avaliar a penetração trans-amelodentinária do peróxido de hidrogênio $\left(\mathrm{H}_{2} \mathrm{O}_{2}\right)$ aplicados em dentes bovinos pigmentados com chá preto em diferentes intensidades. Divisão dos grupos: $A D$ em água destilada; CP100 em uma infusão de 1,6 g de chá preto para $100 \mathrm{~mL}$ de água destilada; CP10 em uma infusão de 1,6 g de chá preto para $10 \mathrm{~mL}$ de água destilada. Todos os grupos foram imersos por 6 dias. Para quantificar a penetração de $\mathrm{H}_{2} \mathrm{O}_{2}$, as amostras foram colocadas em câmaras pulpares artificiais (CPAs) e submetidas a um tratamento clareador com $\mathrm{PH}$ a 38\%, uma vez por semana durante 3 semanas. Após 
o tratamento clareador, a solução tampão de acetato das CPAs com a enzima da peroxidase, foi avaliada num espectrofotômetro de reflexão. A penetração trans-amelodentinária de $\mathrm{PH}$ e os valores de $\mathrm{L}^{*}$ obtidos em T1, T2 e T3 foram submetidos ao teste estatístico de Kruskal-Wallis e Friedman. Em T1, a difusão de $\mathrm{H}_{2} \mathrm{O}_{2}$ no $A D$ foi mais elevada do que em CP100 e CP10. Nos outros tempos de avaliação, os valores de penetração no CP100 e CP10 aumentaram e permaneceram semelhantes. Os valores $L^{*}$ aumentaram significativamente em todos os grupos no T1. No T2, os valores $L^{*}$ foram maiores no $A D$ e os valores em CP100 e CP10 foram semelhantes entre si. No último tempo, o CP10 apresentou os menores valores de $L^{*}$. Diferentes niveis de pigmentação não afetaram a penetração de $\mathrm{H}_{2} \mathrm{O}_{2}$ através do esmalte e dentina e 0 agente de clareador foi eficaz na alteração cromática.

\section{Acknowledgements}

This investigation was supported by FAPESP (The São Paulo State Research Foundation Grants \#2015/01366-4 and \#2014/11748-9).

\section{References}

1. Dahl JE, Pallesen U. Tooth bleaching - a critical review of biological aspects. Crit Rev Oral Biol Med 2003;14:292-304.

2. Haywood VB. Current status of night guard vital bleaching. Compend Contin Educ Dent 2000;28:10-17.

3. Sarrett DC. Tooth whitening today. J Am Dent Assoc 2002;133:15351538.

4. Berg CA, Forner NL, Amengua LJ. At-home vital bleaching: a comparison of hydrogen peroxide and carbamide peroxide treatments. Med Oral Patol Oral Cir Bucal 2006;11:94-99.

5. Lee BS, Huang SH, Chiang YC, Chien YS, Mou CY, Lin CP. Development of in vitro tooth staining model and usage of catalysts to elevate the effectiveness of tooth bleaching. Dent Mater 2008;24:57-66.

6. Sulieman $M$, Addy $M$, Rees JS. Development and evaluation of a method in vitro to study the effectiveness of tooth bleaching. J Dent 2003:31:415-422.

7. Joiner A. The bleaching of teeth: a review of the literature. J Dent 2006;34:412-419.

8. Matis BA, Cochran MA, Franco M, Al-Ammar W, Eckert GJ, Stropes $M$. Eight in-office tooth whitening systems evaluated in vivo: A pilot study. Oper Dent 2007;32:322-327.

9. Arcari GM, Baratieri LN, Maia HP, De Freitas SF. Influence of the duration on treatment using a 10\% carbamide peroxide bleaching gel on dentin surface microhardness: an in situ study. Quintessence Int 2005;36:15-24.

10. Griffiths $C E$, Bailey JR, Jarad FD, Youngson CC. An investigation into most effective method of treating stained teeth: An in vitro study. J Dent 2008;36:54-62.

11. Ubaldini AL, Baesso ML, Medina Neto A, Sato F, Bento AC, Pascotto RC. Hydrogen peroxide diffusion dynamics in dental tissues. J Dent Res 2013;92:661-665.
12. Bowles WH, Ugwuneri Z. Pulp chamber penetration by hydrogen peroxide following vital bleaching procedures. J Endod 1987;13:375377.

13. Benetti $A R$, Valera $M C$, Mancini $M N$, Miranda $C B$, Balducci I. In vitro penetration of bleaching agents into the pulp chamber. Int Endod J 2004;37:120-124.

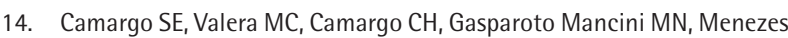
MM. Penetration of $38 \%$ hydrogen peroxide into the pulp chamber in bovine and human teeth submitted to office bleach technique. J Endod 2007;33:1074-1077.

15. Seale NS, Wilson CFG. Pulpal response to bleaching of teeth in dogs. Pediatr Dent 1985;7:209-214.

16. Cintra LT, Benetti F, da Silva Facundo AC, Ferreira LL, Gomes-Filho JE, Ervolino $E_{1}$ et al.. The number of bleaching sessions influences pulp tissue damage in rat teeth. J Endod 2013;39:1576-1580.

17. Costa CA, Riehl H, Kina JF, Sacono NT, Hebling J. Human pulp responses to in-office tooth bleaching. Oral Surg Oral Med Oral Pathol Oral Radiol Endod 2010;109:59-64.

18. Haywood VB, Leonard RH, Nelson CF, Brunson WD. Effectiveness, side effects and long-term status of nightguard vital bleaching. J Am Dent Assoc 1994;125:1219-1226.

19. Gonçalves RS, Costa CAS, Soares DGS, Santos PH, Cintra LTA, Briso ALF. Effect of different light sources and enamel preconditioning on color change, $\mathrm{H}_{2} \mathrm{O}_{2}$ penetration, and cytotoxicity in bleached teeth. Oper Dent 2015;41:82-83.

20. Marson FC, Gonçalves RS, Silva CO, Cintra LTA, Pascotto RC, Santos $\mathrm{PH}$, et al.. Penetration of hydrogen peroxide and degradation rate of different bleaching products. Oper Dent 2015;40:72-79.

21. Williams HA, Rueggeberg FA, Meister LW. Bleaching the natural dentition to match the color of existing restorations: case reports. Quintessence Int 1992;23:673 677.

22. Schmeling M, Maia HP, Baratieri LN. Opalescence of bleached teeth. J Dent 2012;40:35-39.

23. Mottola HA, Simpson BE, Gorin G. Absorptiometric determination of hydrogen peroxide in submicrogram amounts with leuco crystal violet and peroxidase as catalyst. Anal Chem 1970; 42:410-411.

24. Takeuchi $\mathrm{Y}$, Okuno $\mathrm{K}$, Yoshioka $\mathrm{H}$. Characteristics of the $\mathrm{OH}$ radical scavenging activity of tea catechins. J Radioanal Nucl Chem 2007;272:455-459.

25. Soares DG, Basso FG, Pontes EC, Garcia L da F, Hebling J, de Souza Costa CA. Effective tooth-bleaching protocols capable of reducing $\mathrm{H}_{2} \mathrm{O}_{2}$ diffusion through enamel and dentine. J Dent 2014;42:351-358.

Received February 22, 2016 Accepted May 3, 2016 